\title{
Charitable purposes, demonstrable benefit and the role of the Charity Commission: the fourth Pemsel head recast
}

\author{
LARA MCMURTRY*
}

Keele University

\begin{abstract}
The Charities Act 2011 requires that charitable purposes must fit within one or more of the statutory descriptions of 'charity' and, demonstrably, be in the public benefit. From the perspective of the now dismantled fourth Pemsel head of charity, this article examines the elusive concept of a charitable purpose and the misconceived statutory public benefit requirement. The guidance and decision-making roles of the Charity Commission are appraised and problems in applying the current law exposed. As few charity cases reach the courts or Upper Tribunal, this work analyses the limited, but important, registration appeals that have reached the First-tier Tribunal. It will explore the emerging trends in charity appeals, the divergent approaches adopted by the Commission and the Tribunal and the lamentable degree of unpredictability facing prospective charity trustees. It concludes that an absence of clear-thinking pervades this vital aspect of charity law and invites reworking and revision.
\end{abstract}

Keywords: charity; charitable purpose; Charity Commission; Charity Tribunal; public benefit

\section{Introduction}

$\mathrm{U}$ nder the fourfold classification of charity formulated by Lord Macnaghten in Commissioners for Special Purposes of the Income Tax $v$ Pemsel, ${ }^{1}$ the final head focused upon 'other purposes beneficial to the community'. Until its demise brought about by the Charities Act 2006, ${ }^{2}$ this discrete category offered a repository for the diverse grouping of purposes deemed charitable at law and outside the other heads of relieving poverty, advancing education or advancing religion. ${ }^{3}$ It comprised a sundry grouping of established sub-categories, such as the promotion of health, ${ }^{4}$ the welfare of animals ${ }^{5}$ and the promotion of public works, services or amenities. ${ }^{6}$ Taking its inspiration from the Preamble to the 1601 Statute of Charitable Uses, which contained a non-exhaustive list of purposes

\footnotetext{
* I am grateful to Professor Tony Bradney and Professor Warren Barr for their comments on an earlier draft.

1 [1891] AC 531.

2 Repealed by the Charities Act 2011. Unless otherwise stated, all statutory references are to the 2011 Act.

3 To be charitable, a trust must be for a purpose deemed charitable at law, exclusively charitable and for the public benefit.

4 Re Hillier [1944] 1 All ER 480.

5 Re Grove-Grady [1929] 1 Ch 557.

6 British Museum Trustees $v$ White (1826) 2 Sim \& St 594.
} 
deemed charitable at the time of that enactment, the fourth head represented a body of law of 'intolerable messiness', ${ }^{7}$ built up, 'not logically but empirically'. ${ }^{8}$ Nevertheless, it permitted the inclusion of novel purposes by a process of analogy 9 and, thereby, maintained flexibility in the law. ${ }^{10}$ This latter characteristic was appraised as, its greatest strength and most valuable feature'. ${ }^{11}$

The fourth head drew upon centuries of accumulated, and sometimes discordant, case law developments, traceable back to the 1601 Preamble. The Preamble had modestly attempted to illustrate the purposes that might be charitable rather than offering any definition of what comprises a charitable purpose. ${ }^{12}$ It mentioned, for example, the 'relief of aged, impotent and poor people', the 'maintenance of sick and maimed soldiers' and the 'redemption of prisoners'. Nevertheless, it was to assume major significance in the development of charity law, which was to recognise only that 'which the Statute enumerates or which by analogies are within its spirit and intendment'. ${ }^{13}$ Despite its formal interment by the Charities Act 1960, judicial precedent ensured that the Preamble continued to exert influence, especially so with the fourth Pemsel head. Indeed, the fourth head remained inextricably bound to the archaic requirement that any newly admitted purpose must be within the equity of the statute. ${ }^{14}$ If not, the traditional wisdom was that, however beneficial, the purpose could not be charitable at law. ${ }^{15}$

The requirement that a novel purpose was to be sited within the spirit and intendment of the Preamble encouraged the courts to be creative and sometimes stretch analogies, 'almost to breaking point'. ${ }^{16}$ The most striking example was provided in Vancouver Regional Freenet Association v Minister of National Revenue where the provision of internet access was held to be analogous with the repair of highways. ${ }^{17}$ Unsurprisingly, the case for reform was urgent and compelling. As Alan Milburn admitted, 'today's charitable sector would be completely unrecognisable to those who set out the first framework for charitable law, and it is characterised by its huge diversity and enormous size'. ${ }^{18}$ The Charities Act 2011 marked the culmination of a review and consultation process aimed at reinventing the legal definition of charity with heightened emphasis upon public benefit. ${ }^{19}$ This delivered the fatal blow to the Pemsel classification, which was replaced by a more comprehensive list of statutory descriptors. The fourth head was dismantled and reconstituted in the

7 H Kidd, 'Definition of Charity: A Modest Proposal for a Bit of Divorce' (1992-1993) 1(1) Charity Law and Practice Review 5, 6.

8 See Oppenheim v Tobacco Securities Trust Co Ltd [1951] AC 297, 309 per Lord Normand.

9 See Scottish Burial Reform and Cremation Society v Glasgow City Corp [1968] AC 138.

10 See Re Foveaux [1895] 2 Ch 501. As will become clear, the development of the law by analogy remains integral to charity law.

11 See Home Office, Charities - A Framework for the Future (Cm 694, 1989) [2.11].

12 See B Bromley, '1601 Preamble: The State's Agenda for Charity' (2002) 7(3) Charity Law and Practice Review 209.

13 Morice v Bishop of Durbam (1804) 9 Ves 399, 405 per Sir William Grant MR.

14 A continuing process described by Kidd (n 7) as that, 'game of inspecting the Sibylline book of 1601'.

15 Re Strakosch [1949] Ch 529; see also Lord Simonds in Gilmour v Coats [1949] AC 426, 442.

16 Scottish Burial Reform and Cremation Society (n 9) 153 per Lord Upjohn.

17 (1996) 137 DLR 406. See further A Iwobi, 'Rolling Down the Information Highway in Search of Charitable Status' (1998) 5 Web Journal of Current Legal Issues.

18 HC Deb 26 June 2006, vol 448, col 44.

19 See, generally, the Labour Government's Strategy Unit Report, Private Action, Public Benefit: A Review of Charities and the Wider Not-for-Profit Sector (Cabinet Office, September 2002). 
guise of the individual descriptions set out in s 3(1)(d)-(l). ${ }^{20}$ The laudable ambition was that this 'expanded list of purposes would make the overall framework much clearer both for charities and for the public'. ${ }^{21}$ Accordingly, Parliament required that a purpose must fall within one or more of the 13 replacement statutory heads and that it be demonstrably in the public benefit.

Regrettably, the Act refrained from charting the parameters of its public benefit requirement. Two related provisions, however, assume relevance. First, s 4(3) states that public benefit is to be interpreted 'as that term is understood' for the purposes of the law of charity in England and Wales. This reinforces the pre-existing understanding of public benefit ${ }^{22}$ and ensures that the pre-existing case law, however anomalous, must necessarily pervade the current law. ${ }^{23}$ Secondly, s $4(2)$ has sparked controversy, despite its seemingly innocuous wording. This provides that, in determining whether the public benefit requirement has been satisfied, it is 'not to be presumed that a purpose of a particular description is for the public benefit'. As will be discussed, this provision was designed to end the operation of the so-called 'presumption' of public benefit ${ }^{24}$ that was generally, but not universally, believed to have aided the courts in previous times. ${ }^{25}$ Instead, an intrinsic benefit must now be demonstrated affirmatively in all cases. A key problem that is addressed in this article concerns how this aspect of public benefit is to be evidenced in any given case, particularly those under the unpacked fourth head. The enigmatic nature of public benefit continues to cause problems both for prospective applicants and the Charity Commission, and it may now be time to consider afresh the prospect of formulating a statutory definition. Parliament's failure to draw out meaning, and to deal with attendant implications, has generated unnecessary and unwanted practical difficulties. Accordingly, the present work will appraise the difficulties of establishing a public benefit within this changed legal landscape as dominated by the Charity Commission and the Charity Tribunal, blighted by conceptual uncertainty and obscured by linguistic unfamiliarity.

\section{THE DECISION-MAKERS}

Taking centre stage in the post-legislative arena is the Charity Commission, which determines which institutions and purposes are to be categorised as charitable. ${ }^{26}$ The importance of the registration process cannot be underestimated as it provides an assurance that the extensive fiscal privileges that attach to charitable status are deserved. There are also the reputational advantages that come with enhanced public standing, instilling confidence that such charities operate for the public benefit. Significantly, the Commission is, by s 17(1), tasked to provide guidance to promote awareness and understanding of the public benefit requirement. While the Commission is not technically

20 Some of the newly listed purposes were imported from the other pre-existing heads, for example, the promotion of the arts (in s 3(1)(d)) from the 'advancement of education'.

21 Private Action, Public Benefit (n 19) [4.12].

22 As J Hackney observed in 'Charities and Public Benefit' (2008) Law Quarterly Review 347, 347, 'this section effects no change at all'.

23 See, for example, the strikingly conservative approach of the Upper Tribunal in AG v Charity Commission [2012] UKUT 420 (TCC), upholding the charitable status of benevolent funds for the relief of poverty amongst family members and employees.

24 See Hillary Armstrong, HC Deb 26 June 2006, vol 448, col 25.

25 The existence of this presumption was denied in ISC v Charity Commission [2011] UKUT 421 (TCC) (hereafter ISC) but previously was thought to apply to trusts in the first three Pemsel categories.

26 See generally R Meakin, The Law of Charitable Status: Maintenance and Removal (Cambridge University Press 2008). 
a lawmaker, it undoubtedly enjoys a role as a quasi-judicial arbiter of status. Absent rectification of the register, s 37(1) states that registration by the Commission is conclusive of charitable status. It is important, therefore, that registration decisions are robust, fair and consistent and that the public benefit guidance is comprehensive and on all fours with traditional judicial wisdom. This article will establish that these ideals are not always achieved. The Commission has already suffered the chastening effect of a successful legal challenge to its public benefit guidance as regards education ${ }^{27}$ with the subsequent need to revisit its guidance and accompanying legal analysis. ${ }^{28}$ Admittedly, the Commission is not helped in its task by the paucity of cases reaching the courts or the Upper Tribunal. Only a modest measure of oversight and redress is provided by the Firsttier Tribunal (Charity). ${ }^{29}$ Although not a court of precedent and with its proceedings being geared to 'the procedural informality and quasi-inquisitorial approach characteristic of tribunals', ${ }^{30}$ its key role is to consider afresh contested decisions as to eligibility for charity registration. As will become clear, the Commission's ideals are not always shared and important differences in approach between the bodies have come to the fore.

A limited (but ever-growing) number of First-tier Tribunal decisions paint a revealing picture of the existing tension and uncertainty in the Commission's explication and application of the revamped code. From the perspective of the fourth head in its contemporary and disassembled form, this article will critically examine the interpretation and impact of this redefinition of charitable purpose and public benefit. This is an aspect of charity law that has hitherto been neglected, with academic and judicial attention having been focused instead upon the more conspicuous heads of poverty, education and religion. Two problems inherent in the redefined concept of a charitable purpose will be exposed and examined. The first is conceptual and derives from the lack of settled meaning in the statutory language and open-endedness of the descriptions. This is directly attributable to the failure of Parliament to offer adequate statutory guidance or clarification. The second lies in the climate of uncertainty that shrouds public benefit, in particular, the Commission's interpretation of benefit and what it asks of an organisation in order that its public 'benefit' be established. It will become apparent that the Commission operates with an acute awareness of the threat of ambiguity in an organisation's objects and, by insisting upon compelling formal proof of impact, sets an unrealistically high bar to be overcome. While the desire to impose rigour and order in its decision-making process may be laudable, this article will demonstrate that the Commission becomes overly mired in legal technicality. Unsurprisingly, this tendency impedes the valuable, innovative and philanthropic efforts of those at the forefront of charitable endeavour and generates unpredictability and uncertainty for prospective charity trustees. Both these problems will now be considered in turn.

\section{Inherent uncertainty and conceptual misgivings}

The decision to update the list of charitable purposes was popular, uncontested and produced a wider range of descriptions of charity with a decidedly contemporary feel. With some notable amendments in scope, the first three heads were retained and duly

27 ISC (n 25).

28 See, generally, M Synge, The New Public Benefit Requirement (Hart 2015) 219-231.

29 See D Morris, 'The First-tier Tribunal (Charity): Enhanced Access to Justice for Charities or a Case of David versus Goliath’ [2010] Civil Justice Quarterly 491.

30 A McKenna, 'Should the Charity Tribunal be Reformed' (2011-2012) 14 Charity Law and Practice Review 1, 4. 
modified. ${ }^{31}$ As mentioned earlier, the unhelpfully opaque 'other purposes' head was unceremoniously dismantled and replaced by specific, individual descriptions of the purposes. Undoubtedly, the revised list of statutory descriptions reflects more completely the breadth and scope of charitable purposes pursued in modern times. While a number of these purposes had long been held to be charitable, ${ }^{32}$ others are of a more recent vintage. ${ }^{33}$ Importantly, the promotion of existing charitable purposes to new delineated statutory categories serves to enhance the status of those purposes and emphasise their legitimacy. It also underscores an equivalence of treatment with no evident intention to prioritise or distinguish on the merits of a claim to fiscal privileges. ${ }^{34}$ Hence, communityorientated ends, such as the promotion of amateur sport, sit alongside fundamental humanitarian purposes such as the promotion of human rights or the saving of lives. The forms of benefit are diverse, often focused upon fulfilling a specific need, ${ }^{35}$ but sometimes are indirect and of broader benefit to the wider community. ${ }^{36}$ In the absence of demand to extend its number, ${ }^{37}$ there is a sense of permanence to this statutory list. It is not possible to alter the descriptions in light of changing social circumstances or with a view to adding to, or subtracting from, the list. The flexibility so prized at common law is, however, preserved by s $3(1)(\mathrm{m})$. This residual category reflects, 'the way in which charity law has developed in extending incrementally . . . analogy upon analogy, the legal concept of charity'. ${ }^{38}$ Recognised purposes that do not feature in the list continue to be charitable, ${ }^{39}$ as do purposes that 'may reasonably be regarded as analogous to, or within the spirit of' a recognised charitable purpose or a purpose analogous thereto. 40

There is no doubt that the shift from the historically recognised heads of charity to a longer list of statutory descriptions has generated concerns for organisations whose purposes might have formerly fallen under the fourth Pemsel head. As Buckley recognised, 'a lot of unanswered questions remain ... it is both uncertain what these new categories comprise and what, in turn, should be the appropriate test of public benefit in respect of each of them'. ${ }^{41}$ Obvious problems are faced by prospective charity trustees who are confronted with a list of descriptions that are couched in novel language and are not defined more fully. As will become clear, the stark reality is that an institution has to demonstrate that it is established exclusively for charitable purposes in circumstances where the confines of the descriptions are not fully understood. Hence, the key

31 The relief of poverty was widened to encompass the 'prevention or relief of poverty' (s 3(1)(a)), and the scope of religion was to include 'a religion which involves belief in more than one god' or that 'does not involve belief in a god' (s 3(2)(a)).

32 An obvious example is the advancement of the arts, which appears explicitly in s 3(1)(d) and is recognised as charitable in celebrated cases such as Re Verrall [1916] 1 Ch 100 (National Trust).

33 For example, the promotion of amateur sport, which now enjoys statutory recognition in $\mathrm{s} 3(1)(\mathrm{g})$.

34 For relevant discussions of charity and fiscal privilege, see S Bright, 'Charity and Trusts for the Public Benefit - Time for a Re-think’ [1989] Conveyancer and Property Lawyer 28; J Warburton, “'Charity” - One Definition for all Tax Purposes in the New Millennium?’ [2000] BTR 144.

35 See s 3(1)(j) ('the relief of those in need by reason of youth, age, ill-health ...').

36 For example, the advancement of environmental protection or improvement (s 3(1)(i)).

37 See Lord Hodgson, Trusted and Independent: Giving Charity Back to Charities - Review of the Charities Act 2006 (TSO, July 2012) [4.15].

38 ISC (n 25) [77].

39 As H Picarda observed in The Law and Practice Relating to Modern Charities (Butterworths 1977) 108: 'No list of charitable purposes can be exhaustive and it is perhaps inevitable that any classification of purposes will leave a rag bag of individual charitable gifts with no easily discernible common thread.'

40 S 3(1)(m)(ii), (iii).

41 C Buckley, 'The Charities Act 2006: Consolidation or Reform?' (2008) 11(1) Charity Law and Practice Review 1,42 . 
registration decisions of the Commission, coupled with the trickle of appeals to the Firsttier Tribunal, offer for the first time the opportunity to examine this emerging obstacle to charitable status. ${ }^{42}$

\section{DECODING THE STATUTORY LANGUAGE}

Undoubtedly, the unfamiliarity of the statutory wording and the open-endedness of the descriptions combine to generate conceptual and practical problems for the Commission. In contrast with the well-established categories of charity, many of the new descriptions lack both clarity and meaning. The finding that a particular purpose falls within the concept of education, for example, renders it self-evidently beneficial because the legal meaning of education is so innately understood as including certain elements and precluding others. It necessarily excludes a range of purposes that might be deemed political, subversive, lacking in utility or subjective merit. As Garton explains, 'a prima facie charitable purpose is rendered non-charitable because it delivers only an intangible or inefficacious benefit, or has detrimental side effects'. ${ }^{43}$ In comparison, many of the newly formed descriptions remain vague with untested boundaries and only limited or fact-specific case law illustrations from which to distil general principles. Particular problems for prospective trustees have emerged in the context of human rights and community development.

In Human Dignity Trust $v$ Charity Commission for England and Wales, ${ }^{44}$ the Human Dignity Trust (HDT) was established to assist persons whose human rights were violated by the criminalisation of private, adult, consensual, homosexual conduct, and it sought recognition as a charity under s 3(1)(h) of the 2011 Act. The Commission refused initially to register the Trust because, in campaigning for a change in the law, it was political in nature. Of present interest, however, is the Commission's strikingly conservative view of the concept of human rights, surprisingly at odds with its own prior thinking. Citing the lack of clarity as to what human rights means in English law, the Commission favoured a narrow interpretation of the concept, which was to the detriment of the Trust. Ironically, this contradicted its previous, valuable efforts to produce encompassing non-statutory guidance with a broad conception of human rights, ${ }^{45}$ upon which the Trust had not unreasonably sought to rely. It fell to the First-tier Tribunal to take the more confident stand that the 'broad, undefined description of a purpose in the Act was intended to build upon the valuable work already undertaken by the Charity Commission'46 and that the scope of rights falling within the description was apt to, 'evolve and change from time to time, ${ }^{47}$ With characteristic liberality of reasoning, ${ }^{48}$ the appeal against the refusal of the Commission to register the Trust as a charity was allowed. Concerned with interpreting and protecting superior constitutional rights, the purposes were, in its view, geared to upholding the law, not changing it.

42 Note that First-tier Tribunal decisions, 'turn on their own facts and have no precedent value': A McKenna, 'The Charity Tribunal - Where To and From' (2014) 4 Private Client Business 213, 214.

43 J Garton, Public Benefit in Charity Law (Oxford University Press 2013) 47.

44 CA/2013/0013, 9 July 2014 (FTT (Charity)) (hereafter HDT).

45 Charity Commission, The Promotion of Human Rights (RR12) (1 January 2012).

46 HDT (n 44) [42].

47 Ibid [44].

48 Here, the Tribunal has been criticised for its reliance upon, 'highly vague generalities to describe what "human rights" means for purposes of charity law' (see A Parachin, 'Charity, Politics and Neutrality' (2015-2016) 18 Charity Law and Practice Review 23, 37). 
A further illustration of uncertainty may be found in the context of 'community development', which forms part of s 3(1)(e) along with the advancement of citizenship. ${ }^{49}$ It is understandable that 'community development' should assume a place on the statutory list. There is a wealth of Commission guidance on what might be caught by this description, ${ }^{50}$ and it is largely due to the Commission's endeavours that community development has become a category of modern-day charitable enterprise. The Commission's decision in 2003 to register Guidestar UK, for example, admitted as charitable the new purpose of promoting the voluntary sector. ${ }^{51} \mathrm{It}$ is logical, moreover, that trustees might look to that existing Commission guidance for assistance in interpreting the law. The problem remains, however, with the paucity of assistance offered to trustees, anxious to demonstrate that their purposes are exclusively charitable within the bounds of the description. Such was evident in Full Fact $v$ Charity Commission for England and Wales, ${ }^{52}$ where the independent fact-checking organisation, Full Fact, failed in its initial attempts to obtain charitable status with purposes that included the advancement of civic responsibility and engagement. The First-tier Tribunal admitted that the 'promotion of civic responsibility' was, 'undefined by the courts'. ${ }^{53}$ It was, moreover, troubled that the term 'civic engagement' was not necessarily within the same sphere as 'civic responsibility' and, accordingly: 'It cannot be assumed that "engagement" is always positive and capable of providing benefit. 54 Although the Commission was later to accept a renewed application from Full Fact, it was with an objects clause that fell entirely within s 3(1)(b) of the Act (i.e. the advancement of education). ${ }^{55}$ It is troubling that Full Fact was unable to establish that its purposes fell within the specific sphere of charity it preferred to pursue. It came to appreciate that it was manifestly more difficult to structure its objects to those desired ends.

\section{EXCLUSIVITY OF CHARITABLE PURPOSE}

Not only is the statutory language novel, the new descriptions are troublingly open-ended, such that both charitable and non-charitable activities might be pursued. ${ }^{56}$ For Lord Hodgson, it was contentious that a statutory list of charitable purposes 'may include purposes which are not in fact charitable'. ${ }^{57}$ He readily identified an anomaly that 'an organisation with the express object of "relieving poverty" may be regarded by the Commission as having charitable purposes ... but an organisation with the express object of "advancing amateur sport" may not". ${ }^{58}$ Such is well illustrated in Uturn where the company lost its appeal against the refusal by the Commission to register it as a charity. The primary object of Uturn was to promote and set up street associations to 'advance citizenship and community development'. More specifically, its ambition was 'to bring the

49 S 3(2)(c)(ii) provides that this includes the promotion of civic responsibility and volunteering.

50 See Charity Commission, The Promotion of Rural and Urban Regeneration (RR2) (1 March 1999); The Promotion of Community Capacity Building (RR5) (1 November 2000).

51 See Charity Commission, The Promotion of the Voluntary Sector for the Benefit of the Public (RR13) (1 September 2004).

52 CA/2011/0001, 26 July 2011 (FTT (Charity)) (hereafter Full Fact).

53 Ibid [7.3].

54 Ibid.

5517 September 2014.

56 See Uturn UK CIC v Charity Commission for England and Wales CA/2011/0006, 27 February 2012 (FTT (Charity)) (hereafter Uturn) where at [8] the 12 specific heads of purpose were seen as no more than, "potentially charitable'.

57 Hodgson (n 37) [4.15.2].

58 Ibid. 
residents of streets together in local groupings with a framework that will engender civic responsibility and volunteering'. This primary purpose appeared to fall squarely within s 3(2)(c), with street associations the particular vehicle adopted to promote one of the stated descriptions of charity. The Tribunal, however, shared the concern of the Commission that the expression 'street association' did not carry any settled meaning in law and warned that 'the framing of a purpose by reference to an expression, the meaning of which is uncertain, risks the meaning of the purpose itself being unclear or uncertain'. ${ }^{59}$ In deciding that the purposes of the company were not exclusively charitable, the Tribunal made clear that, "for any purpose to be charitable (whether it is new or well established), it must be sufficiently certain, to permit an assessment of whether it falls exclusively within the heads of purpose listed ... in the Act'. ${ }^{60}$ This is a conclusion manifestly more difficult to reach where the content of those heads of purpose remains alarmingly unsettled.

The decision in Uturn is a reminder that merely to adopt the language of the descriptions as a means to communicate the objects of an organisation will not necessarily satisfy the Commission or the Tribunal that an organisation is confined to the pursuit of exclusively charitable purposes. More is required than a statement that a legally recognised benefit lies at the heart of an organisation's purposes. ${ }^{61}$ By corollary, it can be argued that more might be expected in terms of effective guidance to prospective charity trustees seeking to situate their objects within the new descriptions. In Uturn, the Commission identified a lack of clarity regarding the operation of street associations. The admitted concern (shared also by the Tribunal) was that an association might 'provide services to individuals which confer a private benefit'. The Commission was looking, therefore, for a high degree of certainty regarding the future operational activities of each association that would ensure that, in practice, it worked towards exclusively charitable ends. Uturn could not meet that threshold even though its street association project offered a fresh and innovative response to a pressing social problem.

\section{Ambiguity and artifice}

As considered above, the lack of settled meaning underpinning the revised descriptions has resulted in a problematic degree of conceptual and legal uncertainty. In consequence, the Charity Commission feels obliged to look beyond the institution's governing document and to consider extrinsic evidence. This approach is not without controversy. In determining whether or not an organisation is established for charitable purposes only, the initial task is to identify the 'particular purpose' (or purposes) of the institution. ${ }^{62}$ This involves ascertaining, 'what the institution was set up to do . . not how it would achieve its objects or whether its subsequent activities are in accordance'. ${ }^{63}$ The authorities are clear that the initial focus must be on the objects clause or its equivalent in the institution's governing document. ${ }^{64}$ The relevant test here is not an activities test, but is instead a test of what an organisation is established to do. As Synge explains, 'charitable status is not a transient quality which depends on a charity's activities, but a near permanent quality

59 Uturn (n 56) [20].

60 Ibid [27].

61 A point emphasised in Crocels Community Media Group v Charity Commission for England and Wales CA/2015/0009, 18 July 2016 (FTT (Charity) [23]

62 ISC (n 25) [82].

63 Ibid [188].

64 See Helena Partnerships Ltd v Revenue and Customs Commissioners [2011] UKUT 271. 
which depends on the purposes for which an institution is established'. 65 This echoes the sentiment expressed by Buckley LJ that it is irrelevant 'to inquire what the motives of the founders were, or how they contemplated or intended that the . . [organisation] should operate, or how it has in fact operated'. ${ }^{66}$

Nevertheless, in Helena Partnerships Ltd v Revenue and Customs Commissioners, the Upper Tribunal acknowledged that the court may examine activities 'where there is a doubt or ambiguity about whether the objects of an institution are charitable'. ${ }^{67}$ This qualification to the general rule appears to distinguish between the process of working out what the particular purposes of an organisation are (i.e. what it is established to do) and the attendant matter of whether those purposes are charitable purposes. In Incorporated Council of Law Reporting for England and Wales $v A G$, Buckley LJ offered support for that distinction. He admitted that 'in order to determine whether an object, the scope of which has been ascertained by due processes of construction, is a charitable purpose it may be necessary to have regard to evidence to discover the consequences of pursuing that object'. ${ }^{68}$ There the purpose was identified as being the preparation and publication of law reports and the court felt it necessary to consider extrinsic evidence as to whether the performance of its objects achieved an exclusively charitable purpose.

\section{PURPOSES OR ACTIVITIES?}

Although the Commission purports to follow the courts in applying a purposes test, it readily employs an analysis of activities and proposed activities to gain a proper understanding of the body's true purpose. This enquiry is separate to the determination of whether those purposes will furnish a public benefit, ${ }^{69}$ and it involves an additional, unjustified measure of scrutiny for prospective charities. For Luxton, this approach is problematic because it ignores 'a vital difference between a legitimate regard to activities in order to determine whether they are consistent with the body's charitable purposes and an improper attempt to require charities to show public benefit in their activities' ${ }^{70}$ Nevertheless, the Commission continues to undertake this analysis and does so readily when the purposes of an organisation appear to it to be unclear or ambiguous. Indeed, where the purposes of organisations fall within the new descriptions, this is the prima facie starting point. In HDT, for example, the primary concern was the political element to the purposes, but the Commission was explicit that where an institution purports to advance human rights, it would:

... generally be necessary to consider extrinsic evidence (including evidence about the nature of its activities or proposed activities) because, firstly, there is as yet no 'particular meaning' in charity law of the term 'human rights' and secondly, the promotion of human rights is a broad concept which could include non-charitable activities. ${ }^{71}$

65 M Synge, 'A State of Flux in Public Benefit across the UK, Ireland and Europe' (2013-2014) 16 Charity Law and Practice Review 163, 168.

66 Incorporated Society of Law Reporting for England and Wales v A-G [1972] Ch 73, 99.

67 Helena Partnerships (n 64) [20]. This accords with the views expressed by Garton that there are ways in which activities 'could potentially play a role' (original emphasis) such as in the case of a novel purpose, to 'determine whether that purpose falls within the categories of charity': J Garton, 'Charitable Purposes and Activities' (2014) 67 Current Legal Problems 373, 389.

68 [1972] $\mathrm{Ch} 73,99$.

69 See, for example, the decision of the Commission not to register the Countryside Alliance: <www.gov.uk/government/publications/the-countryside-alliance> (23 March 2017) [16].

70 P Luxton, Making Law? Parliament v The Charity Commission (Politeia 2009) 18.

71 HDT (n 44). 
Tellingly, the First-tier Tribunal did not share that hypothesis, finding that HDT's purposes were clear without recourse to extrinsic evidence. The Commission, by contrast, was entangled in an analysis of activities that led it to conclude that a parallel purpose lurked beneath and that HDT was not established for exclusively charitable purposes.

In Vernor-Miles $v$ Charity Commission for England and Wales, moreover, the stated purpose of the Independent Press Regulation Trust (IPRT), was to 'promote for the public benefit high standards of ethical conduct and best practice in journalism'. ${ }^{72} \mathrm{~A}$ separate sub-clause contained a power to expand the objects clause, which included the provision of financial assistance towards the establishment and support of an independent press regulator. The Commission was quick to identify those purposes as ambiguous and focused instead upon the 'express means by which the purpose is to be furthered'. As a Leveson-compliant press regulator was yet to be established, the Commission felt that the purposes of IPRT were too vague and uncertain to conclude that they were exclusively charitable. In its view, IPRT was promoting a concept that had yet to be established as beneficial for the purposes of charity law, and it was unprepared to reason by analogy in its favour. Once again, the First-tier Tribunal did not agree that the purposes were unclear or ambiguous. It did not share the view of the Commission that a collateral purpose could be discerned and concluded that the particular purpose of IPRT was to be found in its objects clause alone. ${ }^{73}$ It could find no evidence that a 'non-ancillary private benefit would accrue to those in the media industry' and highlighted the 'unchallenged evidence' that any private benefit would be incidental. ${ }^{74}$ It was wrong in principle to require the appellants to prove a negative, which was the insurmountable burden the Commission had imposed on IPRT.

\section{ANCILLARY PURPOSES}

Analysis of the registration decisions reveals a divergence of approach to the key matters of determining an institution's objects and distinguishing purposes from the means of their pursuit. Indeed, the Commission might seem somewhat over-zealous in its efforts to unearth collateral purposes that it suspects might be masked or hidden by the applicant. Judicial support for this robust type of investigative inquiry is, nonetheless, discernible, particularly where political purposes are concerned. For example, Southwood v $A G^{75}$ advocated the use of extrinsic evidence to determine the 'true' (i.e. non-charitable) purposes of an institution and is frequently cited as authority for that proposition. ${ }^{76}$ The briefing papers and project proposals available led the court to conclude that the trust was of an overtly political character and not exclusively charitable for the advancement of education. This has not been universally accepted as being the correct approach. Garton complains that 'The trust's purpose was reinterpreted . . . the correct approach should have been to declare the trust valid as being conceptually for the public benefit, although the activities carried on pursuant to it may well have been in breach of trust. ${ }^{77}$ Nevertheless, it is undeniable that the perceived ambiguity in the stated objects strongly encouraged the use of extrinsic evidence as an aid to interpretation.

72 CA/2014/0022 15 June 2015 (FTT (Charity)) (hereafter IPRT).

73 It benefited from a report outlining the public benefit of the Leveson recommendations (see below).

$74 \operatorname{IPRT}(\mathrm{n}$ 72) [38].

75 [2000] WTLR 1199.

76 See, for example, P Luxton, The Law of Charities (Oxford University Press 2001) 440; P Luxton, 'A Three-Part Invention: Public Benefit under the Charity Commission' (2009) 11 Charity Law and Practice Review 19, 27.

77 Garton (n 43) 85. 
Whatever the merits of a robust enquiry, the Commission has proved itself willing to move beyond even these limits and to seize upon the post-formation activities of a registered charity to make the case that it was not established for charitable purposes. Those problems were demonstrated in the litigation involving the Human Organ Preservation Research Trust (HOPRT). ${ }^{78}$ This decision serves well to highlight some worrying features of the Commission's approach. HOPRT was established by deed of trust in 1990 and entered onto the Register in 1991. Its objects were overtly researchorientated. Primarily, it was to 'conduct promote develop and co-ordinate for the benefit of the public research' with a view to enabling the preservation of human organs after death for transplant purposes and to undertake research 'into the ageing process'. By 2017, the organisation was conducting research and training, providing information and advice, while catering also for the provision of cryopreservation services to members of the public and facilitating the transport of preserved bodies into storage. Following a period of heightened press attention ${ }^{79}$ and spurred by a complaint by a member of the public, the Commission solicited evidence of HOPRT's post-formation activities and took the decision to remove it from the Register. ${ }^{80} \mathrm{It}$ did not reach its decision on the basis that HOPRT had ceased to operate as a charity. Instead, it felt that there was insufficient evidence to show that HOPRT had been established for exclusively charitable purposes. In the view of the Commission, its objects were and always had been the promotion and facilitation of cryopreservation, which did not fall within the purposes set out in its trust deed. Accordingly, its entry onto the Register had been a mistake requiring rectification.

On appeal, the First-tier Tribunal turned its attention to the purposes for which HOPRT was established, but could find no evidence of a sham, misunderstanding or miscommunication at the time of registration that might support the Commission's case of registration by mistake. On the contrary, on the evidence available, ${ }^{81}$ the Tribunal found it 'more likely than not that it was the Commission who suggested the final wording of the objects clause or, at the very least, provided input on the words used' ${ }^{82}$ Furthermore, on a plain reading of the objects clause the Tribunal found no ambiguity. The objects as drafted were 'by design, generous and permissive of a wide range of research activities, including those which were not then feasible but which might become so in the future'. ${ }^{83}$

Although it expressed concern that the trust deed had 'become stale and in need of updating, ${ }^{84}$ the Commission was reminded that the problem was a regulatory matter, unconnected with charitable status. Indeed, the focus of the appeal was not to "conduct a review of all the possible ways in which a charity may satisfy the statutory test for registration'. ${ }^{85}$ Instead, it was simply to determine what HOPRT was established to do.

78 Hipkiss v Charity Commission for England and Wales CA/2017/0014, 23 August 2018 (FTT (Charity)) (hereafter HOPRT).

79 Sparked by media coverage of Re JS (A Child) (Disposal of Body: Prospective Orders) [2017] 4 WLR 1 (a landmark decision allowing a terminally-ill, 14-year-old girl to preserve her body after death).

80 The Commission has the ability to do so under s 34(1)(a), (b).

81 With only limited contemporaneous documentary evidence, much of the evidence presented was circumstantial and hearsay.

82 HOPRT (n 78) [107].

83 Ibid [110]. Note that cryopreservation was not possible at the time the trust was executed.

84 Ibid [119].

85 Ibid [123]. 
The direction was that HOPRT be restored to the Register. ${ }^{86}$ More broadly, however, the decision serves to expose the crippling uncertainties faced by organisations seeking to show that their purposes are clear and exclusively charitable from the objects clause in their governing instrument. The response of the Commission does not always help and its decision to act here was unpredictable, time-consuming and ultimately baseless.

\section{A beneficial purpose?}

As between the Commission and the Tribunal, the preceding analysis exposes the dichotomy in approach to discerning the purposes for which an institution is established and the matter of whether these purposes fall exclusively within one or more of the statutory descriptions. It is not sufficient, however, that a purpose falls within one or more of the new descriptions and that it is exclusively charitable. It must also be for the public benefit. The concept of public benefit is widely understood to have two interrelated aspects. ${ }^{87}$ In its first sense, the purpose must be inherently beneficial in a way that the law deems charitable (i.e. the benefit element of public benefit). In its second sense, that benefit must be visited upon a sufficient section of the community (i.e. the public element of public benefit). ${ }^{88}$ As this article is concerned only with public benefit in the first sense, it does not engage with the required reach or scope of that beneficial purpose once established. The task that remains is to analyse the approach of the Commission to the demonstration of benefit as part of the public benefit requirement. Again, the cases to date paint a picture of needless bureaucracy and conceptual conflation.

\section{ISOLATING BENEFIT}

It is somewhat odd that a separate assessment of benefit may be required once a purpose has been shown to fall within one or more of the statutory descriptions. ${ }^{89}$ The Strategy Unit Report emphasised that the purposes were 'chosen to represent the main areas of charitable activity that can reasonably be anticipated to continue to represent a public benefit'. ${ }^{90}$ For the Upper Tribunal, the effect of the statutory wording is to separate out, in a highly artificial manner, the issue of whether the purpose of an institution falls within the descriptions of charity from whether it is beneficial so as to establish public 'benefit'. ${ }^{91}$ The relevance of the statutory list of purposes is that it 'presents a hurdle: the purpose must fall within one or more of the categories and if it does not the question of public benefit is not relevant'. ${ }^{2}$ The pertinent issue is 'not whether the categories are inherently or necessarily for the public benefit, the focus is on the particular purpose of a particular institution'. ${ }^{3}$ Regrettably, it follows that the claimant with a particular purpose that falls within the descriptions must face further scrutiny with something additional to demonstrate. Albeit tentatively, Synge notes that a separate assessment of

86 The vulnerability of the beneficial class was clearly of influence as (ibid [102]) the Commission was rebuked for the failure to consider how best to support individuals in the event that HOPRT (see $\mathrm{n}$ 78) was removed from the Register.

87 ISC (n 25) [44].

88 J Jaconelli, 'Adjudicating on Charitable Status - A Reconsideration of the Elements' [2013] Conveyancer and Property Lawyer 96, 97, conceives of these elements as being qualitative and quantitative respectively.

89 As P Luxton (n 70) at 6 explains, 'the case law establishes that, once a purpose is shown to be charitable, it is necessarily for the public benefit in the first sense'.

90 Private Action, Public Benefit (n 19) [4.14].

91 ISC (n 25) [82].

92 Ibid.

93 Ibid. 
benefit is not itself objectionable, but argues that inclusion on the list should be understood to signify that they [the purposes] are prima facie beneficial, so that satisfying the benefit aspect requires consideration of possible disqualifying factors, rather than separate evidence of benefit'. ${ }^{44}$ This would seem to be an eminently sensible shift of emphasis, but it directly conflicts with the policy and practice of the Commission, which places the onus firmly on the applicant in every case to demonstrate beneficial impact.

Much attention has been devoted in an effort to discern the scope of the common law presumption of public benefit (if, indeed, it may properly be so described) and the effect of the Act in securing its jettison. ${ }^{95}$ Beyond the enactment of this short statutory provision, Parliament did not seek to define public benefit or alter its pre-existing meaning. The alleged existence of a presumption of public benefit was posited on a statement made by Lord Wright, where the issue before him was the matter of whether the National Anti-Vivisection Society had been established for charitable purposes only. ${ }^{96}$ Acknowledging the somewhat distinctive position of trusts falling under the first three Pemsel heads, he concluded that: 'The test of benefit to the community goes through the whole of Lord Macnaghten's classification, though as regards the first three heads, it may be prima facie assumed unless the contrary appears. 97 Tellingly, he does not employ the term 'presumption', but alludes to an assumption that, in the absence of evidence to the contrary, a purpose in those categories is beneficial. Lord Simonds agreed that without that evidence, 'the court will easily conclude that it is a charitable purpose'. ${ }^{98}$

In the ISC case, however, the Upper Tribunal denied that a presumption of public benefit had ever existed, but acknowledged that there was a 'predisposition', which might be displaced by evidence, argument or a consideration of the purpose in the mind of the judge. Following such displacement, 'evidence would be needed to establish public benefit'. 99 The impact of this 'predisposition' was confined to the benefit aspect of public benefit and it did not serve to preclude the court from arriving at its own conclusions on the matter, 'not by way of assumption, but by way of decision'. ${ }^{100}$ This interpretation is clearly arguable and can be made to fit any expost facto analysis of the case law. Accordingly, the inherently educational benefits of a museum displaying antiques or works of art ${ }^{101}$ may be offset by evidence that the objects displayed are of no inherent artistic or intrinsic value. ${ }^{102}$ The publication of religious writings is readily deemed to advance religion unless the works under scrutiny might 'inculcate doctrines adverse to the very foundations of religion or be subversive of all morality'. ${ }^{103}$ The issue is altogether different where the charitable character of a purpose is also in dispute and the judge may, understandably, require to be convinced of the quality of benefit. The classic illustration

94 Synge (n 28) 223.

95 S 4(2) provides that it is not to be presumed that a purpose of a particular description is for the public benefit'.

96 National Anti-Vivisection Society v IRC [1948] AC 31.

97 Ibid 41.

98 Ibid 65.

99 [2011] UKUT 421 (TCC) [67].

100 AG v Charity Commission for England \& Wales [2012] UKUT 420 (TCC), [39].

101 In Re Spence [1938] Ch 96, 105, the display of arms and antiques in a public hall was deemed, 'an educational object' and, therefore, charitable in status.

102 Re Pinion [1965] Ch 85. As Wilberforce J commented at 95: 'Once a gift is clearly seen to be in the . . educational sphere, it does not prevent the court from ascertaining, if necessary by evidence, whether the gift has any educational tendency.'

103 Thornton v Howe (1862) 31 Beav 14, 20. 
is the trust for the training of spiritualist mediums, ${ }^{104}$ cited by the Upper Tribunal in ISC as its primary example of a case where public benefit could not be assumed. ${ }^{105}$

In ISC, the strident disavowal of any technical common law presumption of public benefit generated surprise, at least in some quarters. In its amended analysis, the Commission acknowledged that it was widely considered that there was a presumption ... although views differed as to the nature and effect'. ${ }^{106}$ Those championing reform were convinced that the removal of every trace of a presumption would ensure the application of 'the same strong public benefit test across all four heads of charity'107 and 'create a level playing field on which all charities will have to show that they are for the public benefit'. ${ }^{108}$ For Luxton, however, s 4(2) had no effect on charitable status, 'because such status is not dependent on any presumption but has been established by law'. ${ }^{109}$ On the basis that the section did not have the impact that was envisaged, the provision came to be viewed as no more than 'a political statement, which has affected practice and perception but hasn't really altered the law'110 or as serving only 'to give expression to the extant practice of the Charity Commission, whereby all charities have been required to demonstrate public benefit in order to be registered as a charity. 111 Sparked by the Commission's initial refusal to register the Preston Down Trust, the perceived difficulties to which religious charities were exposed were voiced loudly in the press ${ }^{112}$ and in Parliamentary debate. ${ }^{113}$ This led to the recommendation of the Public Administrative Select Committee that the 'removal of the presumption of public benefit . . . be repealed'. ${ }^{114}$ The response of the government was unhelpfully trite, that 'it would not be possible to "restore" a presumption of public benefit that may never have existed". ${ }^{115}$ The continuing uncertainty prevalent in the discourse is far from satisfactory and the impact of the reform continues to be contested. ${ }^{116}$

\section{THE FOURTH HEAD: PRESUMPTION AND FALLACY}

As previously indicated, for purposes within the new descriptions the prevailing view was that the test of public benefit would 'remain largely unaffected by the Act'. ${ }^{117}$ Whatever the uncertainties facing charities in demonstrating public benefit for the first time, it was plainly understood that fourth head purposes would be untouched by s 4(2). Understandably, purposes under this Pemsel head were never viewed as benefiting from the

104 Re Hummeltenberg [1923] 1 Ch 237.

105 ISC (n 25) [67].

106 Charity Commission, Analysis of the Law Relating to Public Benefit (September 2013) [12].

107 For the Public Benefit: A Consultation Document on Charity Law Reform (NCVO 2001) [4.1.6].

108 Hilary Armstrong, HC Deb 26 June 2006, vol 448, col 24.

109 Luxton (n 70) 9.

110 Final Report and Recommendations of NCVO's Independent Review of the Charity Act 2006 (NCVO May 2012$) 26$.

111 C Buckley, 'The Charities Act 2006: Consolidation or Reform?' (2008) 11(1) Charity Law and Practice Review $1,41$.

112 See, for example, 'Proposed Changes to Charitable Status' The Times (London, 27 May 2004) 27.

113 See HC 13 November 2012, vol 553, col 36. This was described by Nick Hurd (at col 59) as 'quite a rough day for the members of the Charity Commission'.

114 Public Administrative Select Committee, The Role of the Charity Commission and Public Benefit': Post-legislative Scrutiny of the Charities Act 2006 Third Report of Session 2013-14 (June 2013) [93].

115 Government Response to the Public Administration Select Committee's Third Report of 2013-14: The Role of the Charity Commission and 'Public Benefit': Post-legislative Scrutiny of the Charities Act 2006 (Cm 8700 September 2013) 14.

116 See, for example, R Meakin, 'Taking the Queen's Shilling: The Implications for Religious Freedom for Religions being Registered as Charities' (2017) 178 Law and Justice 57.

117 P Smith, 'Religious Charities and the Charities Act 2006' (2007) 9(3) Charity Law and Practice Review 57, 70. 
presumption of public benefit. ${ }^{118}$ The fourth head differed from the first three as 'unlike them it was not a charitable purpose - rather it merely indicated a quality (that of being beneficial to the community) that any purpose would need to possess in order to enter the ranks'. ${ }^{119}$ As Lloyd LJ acknowledged, 'there is a difference, at least in the process of analysis, between identifying a purpose as charitable within that aspect of the classification, on the one hand, and doing so within one of the first three categories, on the other'. ${ }^{120}$ For novel purposes, two separate issues fell to be addressed. The court would consider whether, in a general sense, the purpose carried any benefit or value. If so, the purpose was required to fall within the spirit and intendment of the Preamble to the 1601 Act.

Only novel fourth head purposes were made subject to a more exacting test of validity, with the need for a distinctive approach to fourth head purposes diminishing as the head became shaped by established groupings of cases. ${ }^{121}$ If a purpose could be housed within an established sub-category, it could, in effect, be assumed to carry benefit in the same way as trusts falling under one of the first three heads. By way of illustration, the welfare of animals had become a well-established fourth head sub-category by the early twentieth century, ${ }^{122}$ for the reason that 'discouragement of cruelty to lower animals ... involved benefit to the community'. ${ }^{123}$ Accordingly, in Re Grove-Grady Hanworth LJ was clear that the 'removal of cruelty to animals' (the primary concern of the testatrix) was an object that 'must clearly be accepted as a charity within the decided cases'. 124 This type of benefit is, however, intangible, unquantifiable and thoroughly anomalous. It is described in typically oblique fashion in the case law through the use of phrases such as the promotion of feelings of morality, the repression of brutality and the elevation of the human race. ${ }^{125}$ Not every trust for the benefit of animals carries this form of benefit to the community. Indeed, Picarda admitted that: 'It is difficult to see how animal charities are within the spirit and intendment of the preamble.' ${ }^{126}$ However, once the capability of benefit (in a legal sense) is recognised, that is, in the identification of analogous case law, the court is involved in exactly the same process of evaluation as would occur under any of the first three heads. Evidence of benefit thus ceases to be of concern and what follows is the taking on board of any countervailing evidence of lack of benefit. The outcome in $\mathrm{Re}$ Grove-Grady is well known. Lord Hanworth MR could find nothing beneficial to the animals or to mankind from a sanctuary 'free from the molestation of man, while all the fauna within it are to be free to molest and harry one another'. ${ }^{127}$

The desire for a strong, universal test of public benefit was built upon the fallacy that benefit under the fourth head could never be assumed, that such purposes were subject

118 As Baroness Scotland explained of the general law (HL Deb 20 January 2005, vol 668, col 885), 'there is a presumption that charities established for the relief of poverty, the advancement of education or the advancement of religion are for the public benefit. However, charities established for all other purposes do not benefit from this presumption.'

119 See Luxton, 'A Three-Part Invention' (n 76) 22.

120 Helena Partnerships Ltd v HM Commissioners for Revenue and Customs [2012] EWCA Civ 569, [65].

121 As J Hackney put it in 'Charities and Public Benefit' [2008] Law Quarterly Review 347, 348: 'these purposes became grouped together into classes, and though the language of the books does not always adequately reflect it, other 'heads' came into analytical existence'.

122 See Re Wedgewood [1915] 1 Ch 113.

123 Per Russell LJ in Re Grove-Grady [1929] 1 Ch 557, 588.

124 Ibid 572.

125 See Re Wedgewood (n 122).

126 Picarda (n 39) 109.

127 [1929] 1 Ch 557, 574. 
to a higher degree of scrutiny and that more robust screening might also apply fittingly to purposes under the first three Pemsel heads. Accordingly, benefit is seemingly demonstrated by the weighing-up of benefit and detriment in a given case, as though the purpose at hand were a novel purpose, and without the assumption that a purpose falling squarely within a statutory description is a beneficial purpose. In its day-to-day assessment of public 'benefit', moreover, the Commission sets a high bar with an unapologetic focus on the means by which a purpose is pursued. The relevant question is, 'not whether the ... [particular] purposes are capable of being for the public benefit, but whether there is sufficient evidence from which it can be concluded that they will result in such benefit' (original emphasis). ${ }^{128}$ 'This is, most certainly, an exacting test for any newly established organisation that might struggle to furnish satisfactory evidence of impact. When challenged on its interpretation of the law in Uturn, the Commission justified its general approach by reference to s $2(1)(b)$ and the 'absolute requirement' now imposed that a purpose be for the public benefit. ${ }^{129}$ In the context of community development, the Commission was forced to concede that its earlier, less rigorous statements to the contrary pre-dated the Act, did not reflect the current law and should be disregarded. It is far from clear that this strict and uncompromising approach to public benefit, which it applies across the board, is either justifiable or fair.

\section{PubliC BENEFIT GUIDANCE}

Pursuant to its public benefit objective, the Commission is required to issue and, from time to time revise, its public benefit guidance. ${ }^{130}$ This is guidance to which charity trustees must have regard when exercising any powers and duties to which that guidance is relevant. ${ }^{131}$ Issued in 2013, the guidance in its current form entirely replaces the earlier 2008 version 132 and comprises three parts. Whereas parts two and three deal with running a charity and reporting on a charity's work respectively, ${ }^{133}$ only the first part (PB1) directly concerns the 'public benefit requirement' as defined in the 2011 Act.

To satisfy the 'benefit aspect' of public benefit, the guidance makes clear that 'the purpose must be beneficial' and 'any detriment or harm that results from the purpose must not outweigh the benefit'. 134 Beyond this broad prescription, the Commission guidance is brief, vague and pitched at a level of generality that offers little insight into the Commission's expectations, method of working or rigorous quality control. Its choice of illustrations is mundane and unchallenging. It clarifies that beneficial means 'beneficial in a way that is identifiable', 'capable of being proved by evidence where necessary' and 'not based on personal views'. 135 The reference to 'where necessary' is immediately eyecatching. The Commission admits that 'In some cases the purpose is so clearly beneficial that there is little need for trustees to provide evidence to prove this', ${ }^{136}$ chiming clearly

128 Uturn (n 56) [40].

129 Ibid [41].

$130 \mathrm{~S} 17$.

131 S 17(5).

132 Charity Commission, Charities and Public Benefit (January 2008).

133 Public Benefit: Running a Charity (PB2); Public Benefit: Reporting (PB3).

134 Charity Commission, Public Benefit: The Public Benefit Requirement (PB1) (September 2013) 5. Based on evidence and not personal views, the Commission will: 'take detriment or harm into account where it is reasonable to expect that it will result from the individual organisation's purpose' (8).

135 Ibid 7.

136 Ibid 8, the Commission noted that, "where the benefit of a purpose is obvious and commonly recognised, there is an even greater need for evidence of detriment or harm to be clear and substantial, if it is to outweigh that benefit'. 
with the view expressed by Vaisey J that, 'there are many cases . . . where the purpose is so obviously beneficial to the community that to ask for evidence would really be quite absurd'. ${ }^{137}$ It is unhelpful, nonetheless, that the Commission provides no more than a solitary example of the most urgent and compelling kind, 'the provision of emergency aid in the context of a natural disaster'. Given that a great many trustees may feel that their purposes are clearly beneficial without the need for probative evidence, it is regrettable that no borderline illustrations are offered to assist. This part of the guidance also fails to convey that the focus of the Commission falls not only on the purpose, but the manner in which the purpose is pursued, leading it to doubt, more often than it might, that benefit will result from the pursuit of the organisation's purposes.

\section{OBVIOUS AND OTHER BENEFITS}

The requirement for formal proof of benefit was contested in the HDT case. HDT had been denied registration by the Commission on the basis that its objects were too vague and its purposes too political. On appeal, the Commission argued that 'the onus of proof fell on HDT to satisfy the Tribunal that its purposes are directed to benefitting the public in a way that is recognised as charitable'. ${ }^{138}$ Accordingly, HDT argued that the eradication of human rights abuses was so obviously beneficial that it did not demand formal proof. Support for this view was found in the Commission's own RR12 guidance which stated that the 'concept of human rights is virtually unanimously endorsed by the countries of the world'139 and that 'there is an obvious benefit in promoting human rights'. ${ }^{140}$ Although the Tribunal did not respond specifically to that argument, it was satisfied by witness evidence presented by HDT which was couched in the language of particular benefits to individuals whose human rights were promoted and protected and the wider benefits to the community at large from having such rights interpreted, clarified and enforced. No evidence of detriment was presented. The Tribunal concluded readily that the 'criminalisation of relevant conduct represents a serious breach of human rights norms' and that there must be 'a public benefit in seeking to interpret, clarify and protect superior constitutional rights'. ${ }^{141}$

To clarify cases where the Commission may ask for evidence, the guidance provides straightforward examples, such as to determine the artistic merit of an art collection or the healing benefits of a therapy. These are uncontroversial and unsurprising and are clearly the type of claims that will necessitate expert evidence to establish their merits. Such evidence was adduced by the Soteria Network as to the efficacy of its alternative healing method. ${ }^{142}$ Organisations that fail to do so will simply fall at the first hurdle. In the application for registration by Hitchin Bridge Club, ${ }^{143}$ the Club sought to be considered under the advancement of amateur sport, which embraces a sport or game which promotes 'health by involving physical or mental skill or exertion'. ${ }^{144}$ To fall within the description, it was necessary to demonstrate associated health benefits of the game and, in reaching its decision, the Commission took account of a body of research

137 Re Shaw's WT [1952] Ch 163, 169.

138 CA/2013/0013 (9 July 2014) (FTT (Charity)) at [102].

139 Charity Commission, RR12: The Promotion of Human Rights (January 2005), [11].

140 Ibid [12].

141 HDT (n 44) [109].

142 See the Decision of the Charity Commission on Soteria Network (1 December 2012) <www.gov.uk/government/publications/soteria-network>.

143 Hitchin Bridge Club, 1 March 2011 <www.gov.uk/government/publications/hitchin-bridge-club>.

144 S 3(2)(d). 
evidence which identified those benefits. The 'benefit' element was established just as soon as it was deemed to fall within the confines of the description. In its separate assessment of public benefit, the Commission had little more to add than a series of generic observations, such as the undoubted benefit of, 'regular mental stimulation' from participation in the game. ${ }^{145}$ The Cambridgeshire Target Shooting Association, however, did not fare so well. ${ }^{146}$ The appellant introduced witness evidence from an experienced target shooter, a retired clinical psychologist, a specialist sports physiotherapist, a reader in human neuropsychology and a consultant physical and chemical pathologist. The claim was undone by the absence of published, discrete scientific research. The Tribunal warned that neither it nor the Commission 'should lightly reach findings, which result in the advantages of charitable status being conferred in respect of activities for which the science base is less than robust'. 147 Presumably, if the Association had demonstrated its rightful place within the description, its inherent benefit would have been established without more ado.

\section{EVIDENTIAL DIFFICULTIES}

The final advice in this part of the Commission's guidance deals with the difficulty of measuring benefit and maintains that it should 'always be possible to identify and describe how a charity's purpose is beneficial, whether or not that can be quantified or measured'. ${ }^{148}$ The example provided is 'developing a person's artistic taste by viewing works of art'. There would be few who would contest the benefit of such a purpose were the works of art of sufficient merit. The greater concern, which arises where some formal evidence of benefit is demanded, focuses upon the quality of evidence required. In its separate Analysis of the Law Relating to Public Benefit, ${ }^{149}$ the Commission acknowledged that: 'The courts have not been uniform in their use of language to describe the test for deciding whether a purpose is for the public benefit." ${ }^{250}$ It added that, 'the quality of the evidence which is required to satisfy this test depends on the circumstances of the particular case'. It follows that detailed guidance is difficult to compile and the outcome of an application to the Commission difficult to predict. In Full Fact, for example, the Commission could be satisfied by nothing less than evidence of external validation and concrete reassurance as to the future operation of the organisation. Its eventual registration took five years to secure and required both the adoption of, 'constitutional provisions for an independent reviewer to periodically assess its work'151 and the provision of supporting references from the UK Statistics Authority, Royal Statistical Society and The Migration Observatory. In this case, the evidence that followed was both robust and compelling.

More interesting, however, are those cases where the Tribunal has reached a different conclusion to the Commission either on the basis of the evidence presented to it or, on occasion, the absence of evidence negating benefit. These decisions serve best to illustrate the fundamental difference in outlook between the two bodies. In striking contrast to the Commission, the Tribunal elects for a broad-brush approach to the

\footnotetext{
145 Hitchin Bridge Club (n 143) [28].

146 Cambridgeshire Target Shooting Association v Charity Commission for England and Wales CA/2015/0002, 23 November 2015 (FTT (Charity)).

147 Ibid [61].

148 Public Benefit: The Public Benefit Requirement (PB1) (September 2013) 7.

149 Charity Commission (n 106).

150 Ibid [50].

151 CA/2011/0001, 26 July 2011 (FT'T (Charity)) [31].
} 
demonstration of benefit, which allows for intuitive responses and much greater flexibility. In Uturn, for example, the First-tier Tribunal acknowledged that the Commission may have been influenced by the absence of evidence of demonstrable benefit. Some five months on from the Commission decision, the Tribunal seemed prepared to accept that satisfactory evidence of benefit could have come first-hand from 'individuals actually participating in (or benefitting from) the activities'152 and described it as 'regrettable' that that growing evidence of beneficial impact was not supported by witness evidence. Admittedly, neither the Commission nor the Tribunal found that Uturn was established for exclusively charitable purposes, and so the question of public benefit was considered by the Tribunal for the sake of completeness. It is difficult to imagine, nonetheless, that such witness evidence would have satisfied the Commission had it been presented at the time. The Commission's evident preference for robust external validation would seem to go much beyond the subjective or self-serving statements of those participating in the activities.

In HOPRT, the Commission and the Tribunal reached contrasting conclusions as to the purposes for which HOPRT was established and on the matter of public benefit. Once the Tribunal was satisfied that HOPRT's particular research-orientated purposes were charitable within the parameters of education, little was deemed to be required by way of formal proof to evidence its benefit. It certainly helped that only minimal evidence was presented to the contrary. In terms of its public benefit assessment, the Tribunal formulated the key question to be whether the research conducted by HOPRT was 'in its broadest sense, a good thing' (original emphasis). ${ }^{153}$ Unchallenged witness evidence was presented to this end, describing benefits in the broadest of terms, such as the giving of comfort to patients and making a mother's death easier to bear. Acknowledging that chances of reanimation were remote, there was little to negate the benefits of the research conducted by HOPRT. Ethical uncertainties had not been an issue in the appeal and no evidence on the matter was presented. In addition, there was no evidence of pressure or false hope for those in receipt of services. As cryopreservation was lawful, unregulated by Parliament and in demand, the Tribunal held that the benefit part of the public benefit requirement was clearly satisfied.

Finally, in the IPRT case, ${ }^{154}$ the First-tier Tribunal swept aside the concerns of the Commission that there was no evidential basis from which the public benefit of a Leveson-compliant system of press regulation might be discerned. ${ }^{155}$ Instead, it again utilised a broad-brush approach without regard for remoteness or future uncertainties. The Tribunal accepted evidence in the form of a written report outlining the public benefit. The founding director of the IMPRESS project ${ }^{156}$ lacked the impartiality to be deemed an expert witness but gave uncontested evidence as to the public benefit of the project and the Tribunal happily endorsed his views. It noted that recommendations had been made in the wake of a thorough public enquiry and that those recommendations

152 CA/2011/0006, 27 February 2012 (FTT (Charity) [42]. The Tribunal was receptive to the fact that a further five street associations had been set up by the date of the hearing and heard descriptions of the benefit that flowed from them, namely new links formed in participating communities and the encouragement of volunteering.

153 HOPRT (n 78) [120].

154 CA/2014/0022, 15 June 2015 (FTT (Charity)).

155 See the Decision of the Charity Commission on the Independent Press Regulation Trust (29 October 2014)

[25] <www.gov.uk/government/publications/independent-press-regulation-trust-iprt>.

156 Another organisation seeking to establish a similar press regulator. 
retained the support of all parties in Parliament. Apparently influenced by matters of public policy, the Tribunal declared that:
. . . if such a regulator cannot be established by the Government for constitutional reasons and ought not to be established by the industry itself for reasons of propriety and public confidence, then the charity sector is uniquely placed to be able to offer both the mechanism and the means by which a benefit to the community as a whole can be achieved. ${ }^{157}$

Such a conclusion was firmly outside the Commission's view of its remit and range of responses.

\section{Conclusion}

This article has identified various problems inherent in redefining the concept of a charitable purpose, specifically from the perspective of the old fourth head. As demonstrated, some of those problems are conceptual, deriving from the lack of established meaning in the statutory language and the open-endedness of the descriptions themselves. Others stem from the elusive concept of public benefit and the strict manner in which it is now interpreted and applied. Understandably, the Commission must approach its task in a robust fashion. It is aware of its role as a gatekeeper, securing the charity brand and guarding officiously the fiscal privileges and reputational advantages attendant to charitable status. In its insistence upon compelling formal proof of impact and invariable focus on activities, there is no doubt that it sets a challengingly high standard that otherwise worthy applicants have struggled to meet. There lies the major obstacle to the fair and inclusive operation of the test for charitable status.

By contrast, the First-tier Tribunal operates with freedom and flexibility. In considering afresh the claim for eligibility to charity registration, the Tribunal does not set out to identify or clarify the errors of the Commission and is able to take into account evidence which was not available to the Commission. ${ }^{158}$ Although not a body generating precedent, the Tribunal's decisions may undoubtedly carry some weight. ${ }^{159}$ Such was the case with HDT, viewed conservatively by some as a 'logical application of the existing law in this field', ${ }^{160}$ but for others as 'most significant', making it 'increasingly difficult to sustain the political purposes exclusion where . . . human rights are at issue'.161 Unfortunately, many of the appeals to the Tribunal have failed to stimulate any meaningful comment. With so few cases now reaching a court of record, serious doubt is cast as to the scope for charity law to develop organically and systematically.

For the applicant, the path to charitable status is daunting and unpredictable. There is an unhelpful absence of developing precedent and little can be gleaned from the Register of Charities as it 'does not exist as a precedent bank'. ${ }^{162}$ It seems to make no difference that an applicant can point to examples of charities registered with purposes that are the similar or analogous to its own. It is clear too that the Commission's subject-specific non-

157 IPRT (n 72) [40].

158 Charities Act 2011, s 319(4).

159 In the words of A McKenna, these cases offer 'a fascinating snapshot of what is really going on': 'How Does Charity Law Develop in the Age of the Tribunal' (2018) 20 Charity Law and Practice Review 25, 32.

160 P Kirkpatrick, 'Human Dignity Trust v Charity Commission for England and Wales' (2015) 2 Private Client Business 73, 73.

161 H Biehler, 'The Political Purposes Exception - Is There a Future for a Doctrine Built on Foundations of Sand?' (2015) 29(3) Trust Law International 97, 102.

162 Crocels Community Media Group v Charity Commission for England and Wales CA/2015/0009, 18 July 2016 (FTT (Charity) [23]. 
statutory guidance cannot be relied upon. Although its work on the Register has been bold and confident, ${ }^{163}$ much of the guidance produced is of its time and does not help to impart 'particular meaning' in the statutory concepts. The authoritative steer is to be found in the, 'previous (binding) decisions of the court rather than . . . [the] guidance issued by a regulator'. ${ }^{164}$ For the disappointed applicant, the First-tier Tribunal may now offer a viable avenue of appeal with reasonable prospects of success. Although manifestly cheaper than undertaking High Court litigation, the price of access to justice in the Firsttier Tribunal may nevertheless be off-putting in terms of the time and effort required to engage with the appeal process and, as will often prove necessary, the associated cost of instructing counsel. ${ }^{165}$

163 See Charity Commission, The Review of the Register of Charities (RR1) (1 October 2001); Charity Commission, RR1A: Recognising New Charitable Purposes (1 October 2001).

164 HDT (n 44) [42].

165 No better illustrated than in Full Fact (n 52) where the registration process took a full five years and cost the organisation thousands of pounds in legal fees. 
